The Turkish Online Journal of Design, Art and Communication - TOJDAC July 2016 Special Edition

\title{
LOCAL MARKETING AND ITS ROLE ON ORGANIZATIONAL PERFORMANCE: A CASE STUDY OF TEHRAN TAX ADMINISTRATION
}

\author{
Parva Mohammadi \\ Master Degree Student Marketing Management Islamic Azad University Central Tehran Branch \\ Mahmood Dahgan \\ Ph.D Associate professor in Governmental Management Azad University Central Tehran
}

\begin{abstract}
The present study tries to investigate the effects of local marketing on Tehran tax administration performance. 5 variables (techniques) of local marketing including (senior management, employees' strategic rewards, appropriate internal communication, developing and training employees, employees' empowerment) have been used for studying its role on organization performance. Sample for the present research has been selected from managers and experts of Tehran tax administration and the sample size comprises of 196 participants. For collecting data to analyze and testing hypothesis, questionnaire has been used. The results obtained from hypothesis testing indicates that the five mentioned variables (techniques) of local marketing enjoy significant effects on organization performance. The results indicate that senior management enjoys the highest priority and employees' empowerment enjoys the lowest priority.
\end{abstract}

Keywords: local marketing, organizational performance, Tehran tax administration

\section{INTRODUCTION}

Customers' satisfaction is the most important issue for all organizations in private and non- private sections. Nowadays customers' expectations and needs have become more complex, their needs have incurred changes and providing services by organizations have become more diverse. In service organizations, qualified and service oriented employees is the most important and substantial factor in providing better services. Therefore, for providing better services and at least external customers' satisfaction, employees (internal customers) must be committed to organization goals and perspectives, they have to enjoy customer- oriented behaviors as well. Thus, organizations must focus their attempts on developing and empowering a cultural organization which pays attention to internal customer (employees) satisfaction as much as external customers' satisfaction.

In fact the main source of superiority and success in service organizations is related to service quality and the human forces who provide such services since quality brigs about customers' satisfaction, efficiency improvement, better performance and profitability. Providing appropriate services also is one of the substantial strategies for achieving organizational goals. In service organizations, employees are directly in touch with customers. Therefore, employees' skills, attitudes and behavior is of prime importance since their behavior has direct influence on customers' attitudes toward organization. Nowadays the importance of organization internal customers (employees) in external marketing programs success has become more obvious. 
Tax organization must pay attention to its employees as the most important intangible asset besides paying attention to its external customers. Paying attention to effective factors in intangible assets (employees) efficiency such as working skill, job satisfaction, job security and communication capabilities has an important role in promoting organization performance. In this regard, Tehran tax administration requires organizational capabilities development for providing appropriate services with high quality. As a result, the present research studies internal marketing effects on organizational performance so that the effect of internal marketing on Tehran tax administration performance become clear.

\section{THEORETICAL FOUNDATION WHAT IS MARKETING?}

Many people assume marketing as sale promotion and advertisement. They argue that companies are always seeking to sell something to their customers. They become surprised when they hear that sale is only a small part of marketing duties. But the fact is that even if sale is the final goal, there are other responsibilities which result in sale promotion. These responsibilities can be presented as recognizing customers' needs, producing high quality products and pricing. Peter Drucker, father of new management, says that marketing aim is promoting sale through relying on awareness of customer such that the provided product or service be compatible with customers' needs. This doesn't mean that sale and promotional attempts lack importance and validity; but the aim is that these two parts form marketing responsibilities. Marketing is defined as a social managerial process through which individuals and social groups provide their needs by producing and exchanging goods. For making marketing definition more clear, first of all we need to elaborate on its basic concepts such as needs, demand, goods, exchange, deal and market. In fact, a concept chain ties us from need to market, then to marketing and at last to social marketing. Common people assume marketing as an attempt for finding more customers. Each organization has certain customers for its products (Khorshidi \& Moghadam, 2003).

\section{INTERNAL MARKETING CONCEPT}

Internal marketing can be defined as recruitment, development, motivation and quality continuity of employees through job as a product and satisfying their needs. In other words, internal marketing is the philosophy of a common relationship between customers and employees (internal customers) of an organization (Kahill, 1995). In a sense, internal marketing is known as an academic, scientific and commercial recognition in promoting employees and customers' satisfaction level.

This branch of marketing science is somehow affected by service marketing and quality management which emphasizes on the significance and needs for creating quality during service providing process. This branch of marketing emphasizes on the relationship between customers and organization internal providers in value making for external customers. This can be manifested as a value chain and tool for developing quality of products, services and interaction of interagency and outside organizations (Ling, 2000). Thus, internal marketing goal is creating confidence from satisfaction between organization employees and developing products and services quality in order to achieve organization external employees' satisfaction and this flows as a process from organization internal customers toward external customers.

Previous studies indicates the positive relationship between organization internal customers (employees) satisfaction and its external customer's job satisfaction. Cohort \& Levine (1992) studies indicates that employees' satisfaction (internal customers) has significant effects on products quality and as a result it brings about external customers satisfaction.

\section{REVIEW OF RELATED LITERATURE}

Kai Fu has carried out a research under the title of "effects of internal marketing by airlines in customeroriented behavior" and he asserts that in most of studies related to internal marketing as well as customer- 
oriented behavior, the relationship between these factors and emotional work has not been studied and there are very limited number of articles regarding this topic with an emphasize on airline. Therefore, this study includes flight attendants emotional job in one model and experimenting its mediating effects between internal marketers and customer- oriented behavior. This research studies internal marketing action as behavior surface activity and deep activity in emotional work as a mediator for creating a model of customer- oriented behavior. This study was carried out using 6 airlines flight attendant. This study is valid using SEM and indicates that internal marketing has a significant and positive correlation with customer- oriented behavior. In analyzing the effects of emotional work mediator, surface and deep measurements indicate that mediator effects have a significant effect on the relationship between needs value and customer- oriented behavior. However, surface and deep measurement indicate that it has a more significant mediating effect regarding the relationship between allowed independence and customeroriented behavior (Kai Fu, 2013).

Rodriguez and Pino have a research titled as "internal and external marketing effects on local public organizations" in which they believe that the aim of their research is expanding the literature related to market orientation and studying the effects of both orientations of internal and external market on financial and non- financial performance in local state sections. The research is a qualitative one and the data is collected through an email poll to one of local public organizations of Portugal (municipality administrative members). Structural equation modelling was used as a tool for analyzing and testing hypothesis. 6 hypothesis were confirmed. The results indicated that dissemination and responding external data has significant effect on non- financial performance. On the other hand, responding and producing external data has a positive effect on external performance.

According to internal market orientation, the results indicated that different sub aspects have less effects on the performance. Producing internal data is the only aspect which has positive effect on organizational performance (financial and non- financial). The results enhance the perspective that there is the need for enhancing internal data aspects and responsiveness in order to increase organizational performance (Rodriguez and Pino, 2011).

$\mathrm{Tu}$ et al have done a research under the title of "the effect of management commitment to internal marketing on employees' attitudes". They study the effect of management commitment to internal marketing on employees' commitment through internal marketing methods. The data was collected from 201 full time employees of 4 and more stars hotel in Mazau, China. The results from structural equation modeling indicates that management commitment to internal marketing is related to internal marketing methods including formal and informal communication while informal internal communications facilitate formal internal communications. Furthermore, management commitment to formal internal marketing and non- formal internal communication influences on employees working attitudes. This research help deeper understanding of internal profitable services chain (Tu et al, 2015).

1. The research model

Research hypothesis

1. Senior management (leadership) influences on Tehran tax administration performance.

2. Employees' strategic reward and encouragement influence on Tehran tax administration performance.

3. Appropriate internal communications influences on Tehran tax administration performance.

4. Developing as well as training employees influences on Tehran tax administration performance.

Submit Date: 10.05.2016, Acceptance Date: 25.06.2016, DOI NO: 10.7456/1060JSE/015

Copyright (C) The Turkish Online Journal of Design, Art and Communication 
5. Employees' empowerment influences on Tehran tax administration performance.

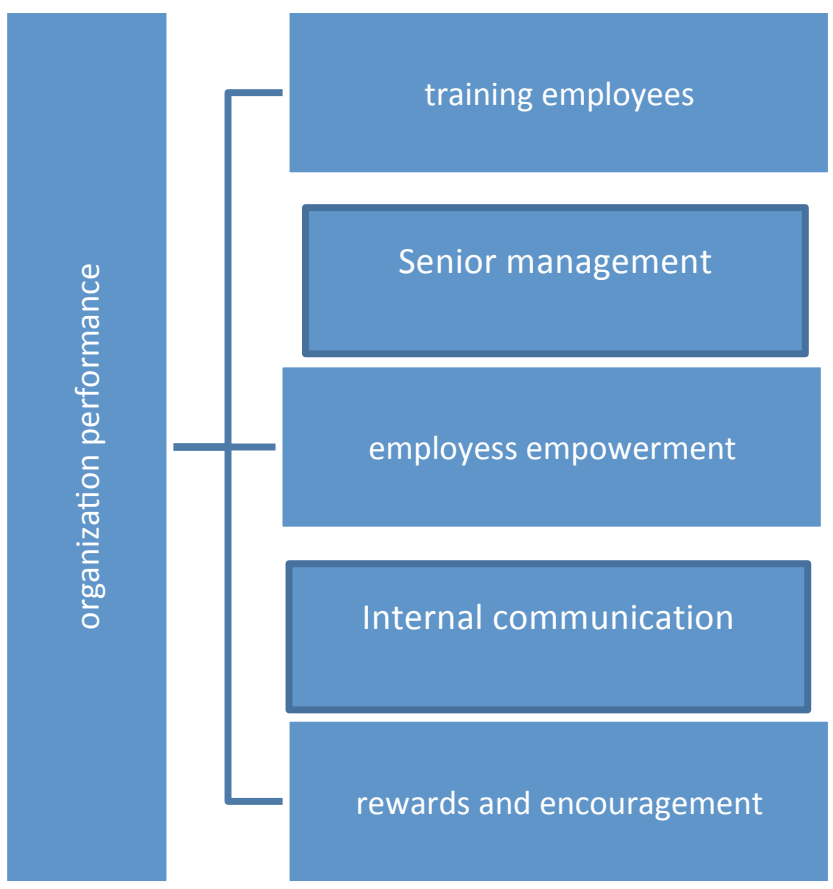

Figure 1- the research conceptual model

\section{THE RESEARCH METHODOLOGY}

The present research is a practical survey and the data is collected through a library research. So, the research can be assumed as a field- library research. The research population comprises of all managers, deputies as well as employees of Tehran tax administration. The population size was equal to 400 individuals and sample is equal to 196 participants which have been randomly selected. According to table 1 questionnaire reliability is equal to 0.742 which indicates a high reliability for the questionnaire.

Table 1- questionnaire reliability statistics

\section{Reliability Statistics}

\begin{tabular}{|r|r|}
\hline $\begin{array}{c}\text { Cronbach's } \\
\text { Alpha }\end{array}$ & N of Items \\
\hline .742 & 36 \\
\hline
\end{tabular}

\section{HYPOTHESIS TESTING FIRST HYPOTHESIS}

Null hypothesis: "senior management (leadership) has no influences on Tehran tax administration performance". 
The Turkish Online Journal of Design, Art and Communication - TOJDAC July 2016 Special Edition

Alternative hypothesis: "senior management (leadership) influences on Tehran tax administration performance".

According to table (4-7) test normal statistics is equal to 10.6 and the obtained amount is larger than 1.64. In this case null hypothesis is rejected, i.e. with the confidence of $95 \%$, senior management (leadership) has an average effect on Tehran tax administration performance.

\section{SECOND HYPOTHESIS}

Null hypothesis: "employees reward and encouragement has no influence on Tehran tax administration performance".

Alternative hypothesis: "employees reward and encouragement influences on Tehran tax administration performance".

According to table (4-7), test normal statistics is equal to 10.62 and the obtained amount in larger than 1.64. In this case null hypothesis is rejected, i.e. with the confidence of $95 \%$ employees' strategic rewards and encouragement has an average influence on Tehran tax administration performance.

\section{THIRD HYPOTHESIS}

Null hypothesis: "appropriate internal communication has no influence on Tehran tax administration performance"

Alternative hypothesis: "appropriate internal communication influences on Tehran tax administration performance"

According to table (4-7), a normal test statistics is equal to 8.9 and the obtained amount is more than 1.64. In this case null hypothesis is rejected i.e. with $95 \%$ confidence appropriate internal communication has an average influence on Tehran tax administration performance.

\section{FOURTH HYPOTHESIS}

Null hypothesis: "developing and training employees has no influences on Tehran tax administration performance".

Alternative hypothesis: "developing and training employees influence on Tehran tax administration performance".

According to table (4-7), it is clear that a normal test statistics is equal to 7.6 and the obtained amount is more than 1.64. In this case the null hypothesis is rejected i.e. with the confidence of $95 \%$ developing and training employees has an average influence on Tehran tax administration performance.

\section{FIFTH HYPOTHESIS}

Null hypothesis: “Employees' empowerment has no influences on Tehran tax administration performance".

Alternative hypothesis: "Employees' empowerment influences on Tehran tax administration performance".

According to table (4-7) a normal test statistics is equal to 8 and the obtained amount is more than 1.64. In this case the null hypothesis is rejected, i.e. with the confidence of $95 \%$ employees' empowerment has an average influence on Tehran tax administration performance.

Submit Date: 10.05.2016, Acceptance Date: 25.06.2016, DOI NO: 10.7456/1060JSE/015

Copyright (C) The Turkish Online Journal of Design, Art and Communication 


\section{RANKING VARIABLES USING TOPSIS MODEL}

After ranking variables using TOPSIS model, variables with higher rank have the priority to be applied. The results from such a ranking is presented in table 4 .

Table 4- the research variables ranking

\begin{tabular}{|c|c|c|c}
\hline $\begin{array}{c}\text { Variable } \\
\text { weight }\end{array}$ & $\boldsymbol{c l}_{\boldsymbol{i}}^{-}$ & Rank & Variable \\
\hline 0.25 & 0.597 & 1 & Senior management \\
\hline 0.2 & 0.55 & 2 & $\begin{array}{c}\text { Employees reward and } \\
\text { encouragement }\end{array}$ \\
\hline 0.2 & 0.445 & 3 & Internal communication \\
\hline 0.2 & 0.43 & 4 & $\begin{array}{c}\text { Developing and training } \\
\text { employees }\end{array}$ \\
\hline 0.15 & 0.403 & 5 & Employees empowerment \\
\hline
\end{tabular}

\section{CONCLUSION}

The present research studies the relationship between these 5 internal marketing variables on Tehran tax administration performance. According to the results it became clear that all of these variables have average influence on organization performance with $95 \%$ confidence. It was also found out that employees empowerment has the least rate of influence comparing to other variables. Senior management variable also enjoys the highest rate in influencing organization performance. This can be very influential in helping organization management for planning, situation analysis, appropriate resources allocation and finally achieving organization goal. Therefore it is suggested that:

1. According to the research results, senior management variable has an average influence and it enjoys the first rank among other variables. Thus, this variable and its related activities especially optimization of employees required technology, paying attention to security issues as well as employees' job hygiene, employees activities management as procedure, promoting organization public image from the perspective of employees) should be considered.

2. According to the research results, employees reward and encouragement has an average influence on tax organization and it also enjoys the second rank among the other variables. In this variable activities such as creating a better working condition and environment for employees, praising employees for doing their duties, promoting employees should be considered.

3. According to the research results, internal communication has an average influence on tax organization performance and it also enjoys the third rank among the variables. In this variable, activities such as specifying employees duties, creating and developing office automation for employees communication, creating team work opportunities among employees should be considered.

4. According the research results, developing and training employees has an average influence on tax organization performance and it enjoys the fourth rank among the variables. In this variable, activities such as increasing organizational commitment among employees, using electronic training should be considered.

5. According the research results, employees' empowerment variable has an average influence on tax organization performance. It also enjoys the last rank among the variables. In this variable, activities 
The Turkish Online Journal of Design, Art and Communication - TOJDAC July 2016 Special Edition

such as increasing skills and job flexibility among employees, employees' replacement and succession, creating sense of freedom of action and independence among employees should be considered.

6. As implementing and using all variables requires planning and costly and as it is timeconsuming, it is not possible to implement all these variables. Therefore, for using and implementing variables, one should pay attention to the variables rank and the priority for implementing them.

7. Gaining support from planners and senior managers and creating believes and appropriate mental pattern regarding the advantages of internal marketing tools and creating a coherent and coordinated system for using them is essential which should be considered when using internal marketing.

8. Establishing a leadership committee for accurate planning and reducing the costs of applying internal marketing in Tehran tax administration can be an appropriate tool for administrating internal marketing.

9. One should study the influence of other variables of internal marketing in future researches so that find those variables which enjoy the most influence to be introduced to the organization.

10. Tax organization has branches in all provinces all over the country. One should try to carry out the present research in different branches (or at least some) and the obtained results should be compared so that usable public variables in all organizations can be recognized and used for improving the organization performance.

11. Organizational condition, human forces features, appropriate management style for organization should be accurately recognized so that internal marketing influence can be increased.

\section{REFERENCES}

Amiri, M. Yazdani, H. Ekran Nosratian, "evaluating internal services quality and internal marketing level of Tehran Gas Co. and the relationship between its internal marketing measurements and external service quality", (2008), Management Knowledge, No 21 (81), Pp 3- 18.

Mazhari, Mohammad, Parsapour, Khadijeh, "studying the effective factors on Rapeseed cultivation acceptance" (2011), Economics and Agriculture development, Volume25, No 4, 410- 419.

Nasr Esfahani, Ali, Farrokhi, Mojtaba, Amani, Mojtaba, "the effects of internal marketing on team working effectiveness in higher education: a case study of Esfahan University" (2012), Commercial management perspective, No. 9.

Hersey, Paul and Keneth Blanchard, "Management of organizational behavior" (2002), 14 ${ }^{\text {th }}$ Edi. Translated by Ali Alagheband (Tehran: Amir Kabir Pub).

Yunesi far, Seyed Mohammad, Mohaghar, Ali, Yunesifar, Seyed Aziz, "the effects of internal marketing components on Yazd Shahid Sadughi Hospital staff performance" (2013), hygiene management, 2 (3-4)

Ahmed, P., \& Rafig, M. Internal marketing issues and challenges. European Journal of Marketing, 11771186. (2003)

Gounaris, S. P. Internal-market orientation and its measurement. Journal of Business Research 59, 432 448. (2006).

Harris, S. O. and Mossholder, K. W. "The Affective Implications of Perceived Congruence With Culture Dimensions During Organizational Transformation", Journal of Management, 22 (4), 527-47. (1996).

Hui Yang, W. Relationships among Internal Marketing Perceptions, Organizational Support, Job Satisfaction and Role Behavior in Healthcare Organizations. International Journal of Management, 235242. (2010). 
Kai Fu, Yan,"The influence of internal marketing by airlines on customer-oriented behavior: A test of the mediating effect of emotional labor",Journal of Air Transport Management,Volume 32, Pages 49-57. .(2013)

Lings, 1. Balancing Internal and External Market Orientations. Journal of Marketing Management, 15, 239-263. (1999).

Lings, lan n "internal marketing and supply chain management", journal of service marketing, vol. 14, pp. 27-43 . (www.emrald-library.com),(2000).

W.M. To , E.F. Martin Jr., Billy T.W. Yu." Effect of management commitment to internal marketing on employee work attitude",International Journal of Hospitality Management, Volume 45, February 2015, Pages 14-21. (2015).

Tsai, Y., \& Wu, S.-W. Internal Marketing, Organizational Commitment and Service Quality. IEEE. (2006).

Yudi Fernando,"Impact Internal markting on Operational performance:an Empirical study in Low cost carrier Industry.procedia-social and behvioral sciences 65(2012),913-918,(2012). 